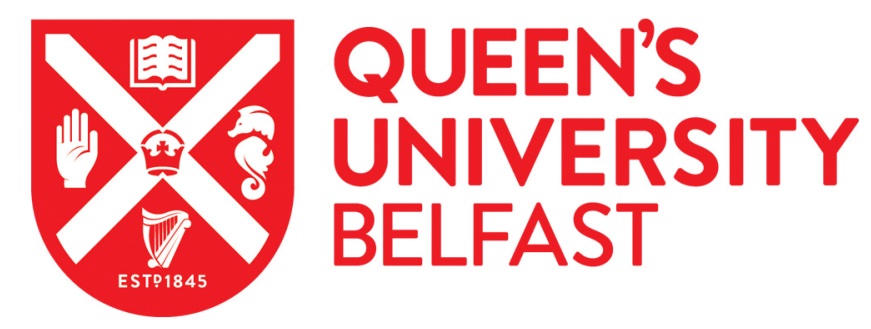

\title{
Wounded Spaces: When Planning Degraded Cairo's Urban Memory
}

Selim, G. (2016). Wounded Spaces: When Planning Degraded Cairo's Urban Memory. Open House International, 41(2), 31 -37.

Published in:

Open House International

Document Version:

Peer reviewed version

Queen's University Belfast - Research Portal:

Link to publication record in Queen's University Belfast Research Portal

Publisher rights

(C) 2016 Open House International

\section{General rights}

Copyright for the publications made accessible via the Queen's University Belfast Research Portal is retained by the author(s) and / or other copyright owners and it is a condition of accessing these publications that users recognise and abide by the legal requirements associated with these rights.

Take down policy

The Research Portal is Queen's institutional repository that provides access to Queen's research output. Every effort has been made to ensure that content in the Research Portal does not infringe any person's rights, or applicable UK laws. If you discover content in the Research Portal that you believe breaches copyright or violates any law, please contact openaccess@qub.ac.uk. 
To cite this article:

Selim, G. (2016) Wounded Spaces: When Planning Degraded Cairo's Urban Memory. Open House International. 41 (2), p. 31 -37.

\title{
Wounded Spaces: When Planning Degraded Cairo's Urban Memory
}

\author{
Gehan Selim
}

\section{ABSTRACT}

This article examines the position of planning practices operated under precise guidelines for displaying modernity. Cultivating the spatial qualities of Cairo, since the 1970s has unveiled centralised ideologies and systems of governance and economic incentives. I present a discussion of the wounds that result from the inadequate upgrading ventures in Cairo, which I argue, created scars as enduring evidence of unattainable planning methods and processes that undermined its locales. In this process, I will focus on the consequences of eviction rather than the planning methods in one of the city's traditional districts. Empirical work is based on interdisciplinary research, public media reports and archival maps that document actions and procedures put in place to alter the visual, urban and demographic characteristics of Cairo's older neighbourhoods, against a backdrop of decay to shift towards a global spectacular. The article builds a conversation about the power and fate these spaces were subject to during hostile transformations that ended with their being disused. Their existence became associated with sores on the souls of its ex-inhabitants, as outward signs of inward scars showcasing a lack of equality and social justice in a context where it was much needed.

Keywords: wounded spaces, scars, Cairo, Bulaq, slums, urban renewal, memory

\section{INTRODUCTION}

\section{'A scene in Ishash al Tourguman, Bulaq Abul Ela, central Cairo, 2015'}

Arrival at the old area of al Tourguman holds images of a gritty past that is still remembered by its residents. Centrally located is a busy traditional coffee shop 'Kahwa baladi', situated in al Sahafa Street, where one normally spots elderly men in their late sixties or seventies, dressed in threadbare outfits and smoking Shisha. They rarely chat or socialise but rather continue to gulp short sips of tea with a mental tape of memories of what used to be their neighbourhood during golden childhood times. Another scene occurs in a tight alleyway: a lady dressed in a black gown sitting selling matchbooks and paper tissues, hoping for nominal revenue to head back home happy. Next to her, a group of kids playing football, vociferously pointing out where they live and work. A majority of these residents are living amidst the remains of their former houses and historical ruins and memories.

The inland of Bulaq slums, the so-called 'ishash', are, and have been, places where prejudiced and imbalanced assessments of land have led to consistent disputes. During the 1970s, under economic reform and high flows of migration to the city, Ishash al Tourguman had become a dangerous place, known for its informal housing, 
degraded infrastructure and drug businesses. The Ishash was described as the centre of anarchy and chaos following a series of riots in Cairo on 18-19 January 1977 against the termination of state subsidies for basic commodities which had led to immediate and rapid price increases. The incident occurred after Egypt's president, Anwar Sadat, embarked on a series of economic reforms in 1974, pursuing an open-door economic policy to encourage foreign and domestic investment in the private sector. However, Egypt's large debt burden soon pushed Sadat to take a series of loans from the World Bank, under the condition that state subsidies for foodstuffs would be severely limited. Furious Cairene residents attacked many symbols of Sadat's luxury lifestyle like hotels, department stores and even police stations. The ishash was then denounced as the hub of a Communist-led uprising of thieves, after groups of activists stashed themselves away in the swarming slums, making the mission of tracking them impossible since the tight streets prevented entry to police vehicles.

It is claimed that the cleansing of popular life in Cairo had started during Sadat's regime with the violent clearance of ishash al Tourguman and displacement of its population. Hundreds of families were evacuated in May 1977 without compensation. Replacing the ishash with high-rise structures reinforced Sadat's claim to be eliminating signs of poverty and decline in Cairo by creating 'a youthful face of Egypt', and indeed low-income groups occupying lands, which potentially carried high values, were not central to the beautification of the capital (GHANNAM, 2002, p. 31). On the national level, city authorities explained that demolition would support the revamping and modernising of the Cairene life. Relocating a portion of its population from brutal living conditions to suitable modern housing units was crucial to improving their living standards. For over two decades, while renewal plans remained firmly on paper, a huge gaping hole marked the grounds of Bulaq where the ishash residents had once lived. In 2001, Cairo's International Bus Terminal, a gigantic project, was constructed on the spot. But for years when travelling to Cairo, and despite many other things happening in Bulaq, one kept bumping in this anecdote: close to the terminal doors, one could still envisage the memory and footage of the clearance and displacement incident, police sirens and weeping toddlers. The ishash formed a narrative of a place of unyielding power cursed by its historical facts that its residents still track and enumerate. Their wounds bled from the heart of one of the world's most fascinating cities, where the state's inauguration of one of its grand architectural projects stopped at nothing in having its vision fulfilled (Figure 1).

The article discusses how wounded spaces, marked by past deficits of power, violence and exclusion in Cairo, are represented and how the spatiality of places remarkably articulates scars that are never cured by time but are still remembered and lived. Do relocation practices require care and attention that limit the violence and difficulty of abandoning a place? My argument is that such wounded spaces in Egypt insinuate the capacity that places should not remain the same physically and socially because they have been profoundly threatening postcolonial imperial processes. This capitalises that whatever is deemed 'traditional' - living in urban slums, uneducated and, mostly, engaged in political instability - is somewhat less legitimate; therefore, traditionalism is often scrutinised in terms of its authenticity and degree of exposure. Nevertheless, restructuring this reality to overlay new depictions on to a place, excluding its individuals and groups, often becomes the normative power of how we reshape our built environments (DAVIES, 2014). These processes 
have taken several forms of forcible action, such as compulsory relocation of people from their districts as one form of control over politicised spaces, with widespread destructive implications for the physical, metaphorical and imaginative spheres.

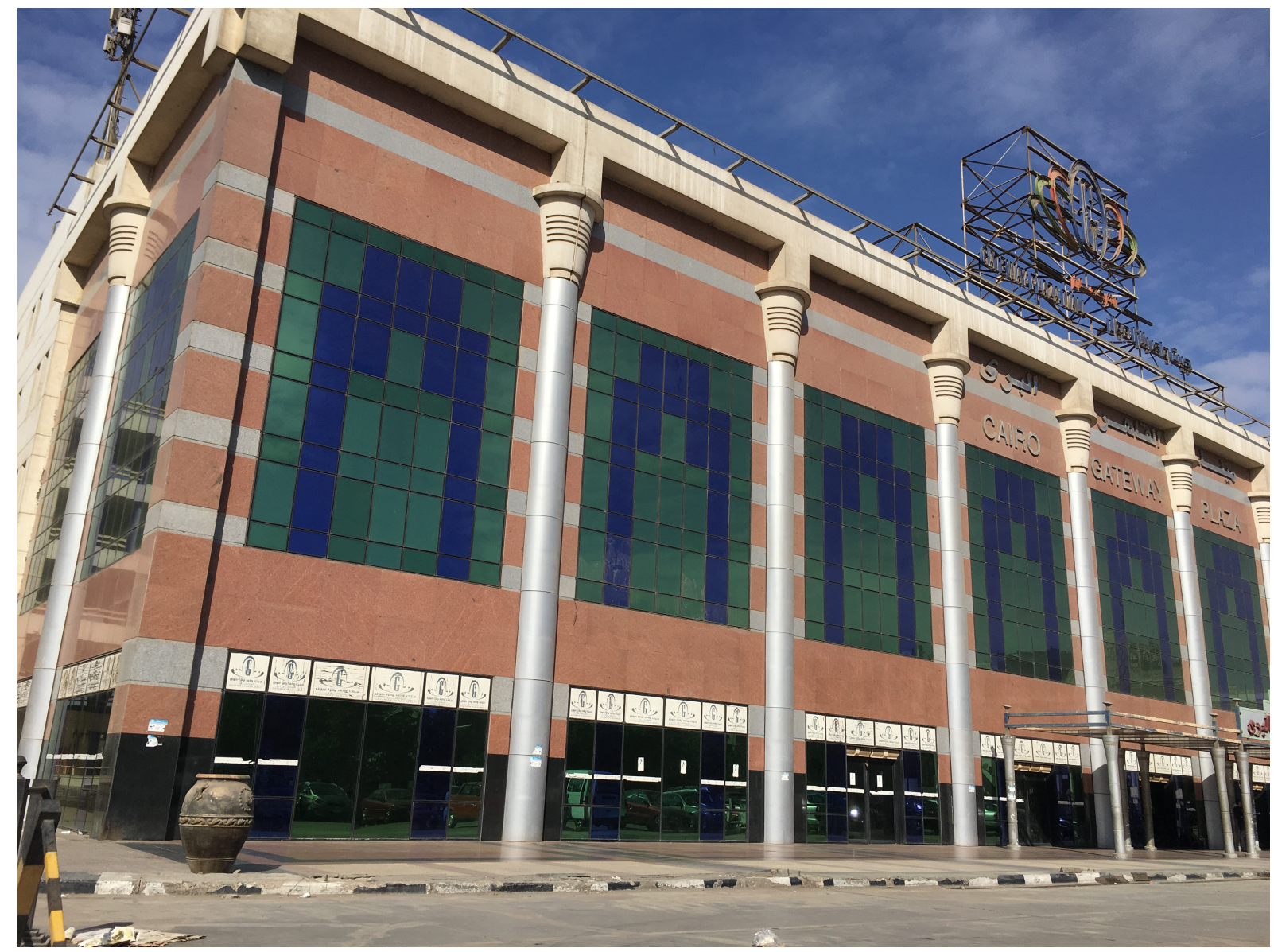

Fig. 1 Cairo's International Bus Terminal constructed on the site of Ishash al-Tourguman slums in Bulaq in 2001.

\section{THE URBAN MEMORY AND ITS POLITICAL INSCRIPTIONS}

Postcolonial research examining urban settlements in the global south has shifted towards radicalising our understanding of cities and how to transmute their physical structures of inconsistencies, conflict and inequality in celebrating residents' lived realisms (SIMONE, 2010; HARVEY, 2003). In the context of contesting the inherited values of modern urban development influenced by governance and governmentality, there still remains the quest to boost urban transformation in the desire for order and sweeping away sore histories. However, this approach is not without its costs. The reason why Western models of urban development, for example, tend to idealise the outcomes that predominantly impact the everyday encounters, practices and social networks of the people. Urban renewal ventures drawing red battle lines around entire districts, for instance, signalled a new urban reality, not only to challenge physical conditions but also to wipe away individual memories of these places 
(BLUNT \& MCEWAN, 2002; ELLIN, 1999). Manuel Castells' account of Parisian urban gentrification in the nineteenth century, aimed equally at elaborating the state's control of public spaces, is pertinent to what motivates governments today: 'A Paris occupied by the higher social strata, a showcase of comfort and modernity, is a Paris cut off from potential outbursts of protest' (CASTELLS ,1972, p. 106).

Various examples show how a city is tacitly privileged by simulating its districts as parcels of land connected by networks of economy; but on the contrary, populated districts appear as blank entities discounted from potential development, leaving residents depicted as victims. We find urban sociologists and geographers retrieving conceptualisations of places, which vary from so-called slums to luxury theme parks and CBDs, as an integration within the city but not, peculiarly, as an add- on (SIMONE, 2010). Michel Foucault's theories on power and control of space in the urban sphere show that modern governance similarly capitalises on various forms of this supremacy. It also reveals the position of the state in operating different security apparatuses to safeguard citizens and their sense of safety by preventing crime and handing over perpetrators to judicial authorities for prosecution. We therefor find that existential insecurity can be politically manipulated to increase the control of space. Violence, for instance, is presented to the public as a case of national security rather than safety in order to curtail the public sphere and influence the community perception of fear (ZUKIN, 1995).

From a postcolonial perspective, imagining the city consequently tolerates our understanding towards systems of urban political life, everyday existence, agitation and disorientated mobilisation of people who are the absolute victims. These socially constructed spaces, according to Henri Lefebvre (1991, p. 220), offer individuals their membership links with the place. Its buildings and streets are grasped as a sign of the legendary nature of the place, one that is as important as the condition of those that lived there. These bonds remain memorised across time largely through material objects that presumably last much longer than we do. Yet, this idea remains unchallenged. But when subject to massive processes of destruction, mobilisation and relocation, dense urban spaces occupied by inherent localities become impaired by spatial relations and social trauma imposed by state violence. Similar to several postcolonial localities, the sweeping away of entire districts has printed its own scars on these places and haunted remaining residents with wounds of past glories, whether they accepted it or not. The wounds reflect a condition of self-remembrance and individual memory embedded in the physicality structure of spatial order away from any external forces of colonial practices and their aftermath (KEARNEY, 2012). These spaces represent instances where local identity was an incipient political project against social and collective memory that demonstrates problematic or disturbing conditions. They are the territories where 'geographical space...has been torn and fractured by violence and exile', shaping a state of newness of physical and social realities that reproduces altered visual images integrated with modern cultural expressions and secured environments (Rose, 1996,p.191). (Figure 2) 


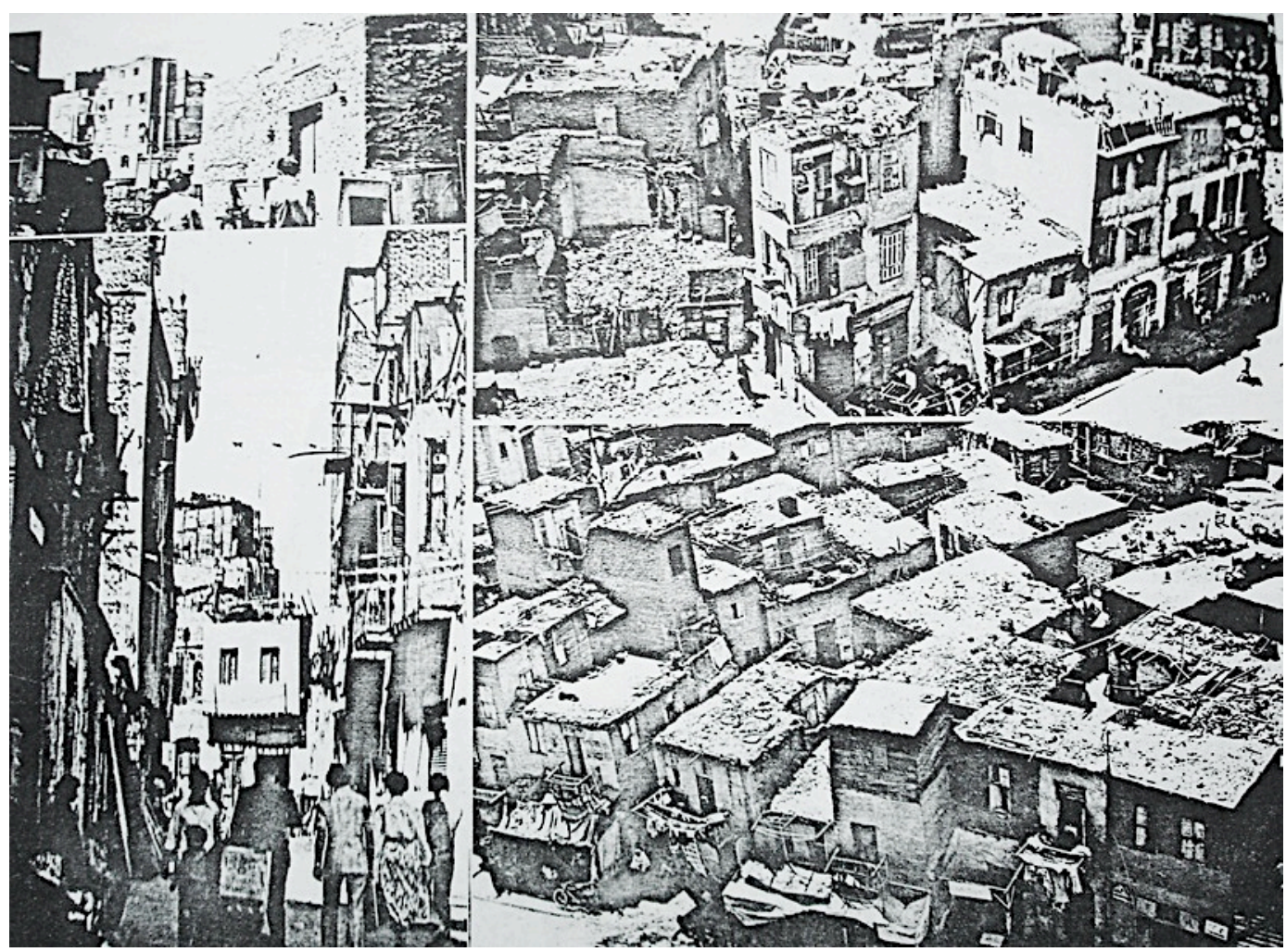

Fig. 2 Ishash al-Tourguman images published in the planning scheme brief. Source: The re-planning scheme Report 1979, GOPP, Cairo.

\section{PLACE REMINISCENCE AND 'ROOT SHOCK’}

We still remember that day when the police suddenly surrounded the area and forced the people to leave their houses; the men bravely fought the police officers, the women were screaming, but they forced them to leave in the end (interview).

Al-Tourguman is a poor area that expanded randomly in Bulaq during the 20th century. The place was originally established by a Turkish merchant named Ali Bek al Tourgoman, whose name it gained, who customised its infrastructure and managed its tenet system until his death. The Ministry of Public Works privately sold wealthy stockholders, including Ali Bek, huge swathes of vacant land outside Bulaq's eastwest border to construct new developments that would aid with the absorption of Cairo's migrant workers. Following Egypt's defeat in the 1967 war, nationwide concerns were raised following the suspension of special government housing projects, particularly when daily newspapers published images of entire communities living in emergency shelters after several evacuation incidents. The government built these settlements as transitional housing systems to shelter homeless people whose houses had collapsed or become seriously damaged as they awaited allocation of housing in new residential settlements. By this time, al-Tourguman and other areas had gradually become dominated by shanty constructs built with light materials and leftover wood, which lacked water, electricity and primary hygiene resources. Thousands of people were crammed into homes that were 'only corners of single rooms that accommodate all the functions of the household members' (RUGH, 1979, p.47). The narrow alleyways rapidly turned into hives of illegal activities, which later 
became popularly known as ishash al Tourguman. People living in Bulaq describe their neighbours as tragic and doubtful. (Figure 2)

The government has neglected them. They no longer have any rights in this country.

They have depressing lives, their homes appear like squats of stacked and glue-like compartments stretching in narrow alleyways overwhelmed by poverty and hunger.

Men and women are jobless with no breadwinner, the elders are homeless and the children surrounded by slums, diseases and hunger. (Interview)

But do memories of places relate to the past or articulate narratives of present human experiences? Or how do locals still living in al Tourguman distinguish between their present lives and the strong connections with the past that historical events evoke? Indeed, the furious escape of the young protestors in the 1977 riots emerged as a serious challenge to the state. People still recall how police vehicles failed to seize the vulnerable 'boys' and feel proud of helping them to escape this raid. Notwithstanding, residents of popular areas in Cairo, like Bulaq, are legendary for their generosity, bravery and care. But since that time, state discourse has homogenised them, under actions of symbolic violence, as troublemakers and criminals, with the district portrayed as a centre for drug trafficking and illegal activities (GHANNAM, 2002). Official action, under the auspices of the Central Security Force, culminated in 1979 with the outrageous displacement of thousands more to the city outskirts, producing what Fullilove (2004) calls the 'root shock'.

Plans to develop al-Tourguman in 1979 subdivided the site into 25 plots under governorate jurisdiction. Local and foreign investors were then invited to submit proposals to inaugurate projects in accordance with the planning scheme, but no plots were actually sold. A respondent from the governorate planning department attributed this failure to financial constraints and professional shortcomings in the project's feasibility study which had estimated that evacuation and relocation would cost the governorate approximately 36 million EG. After clearing the site, however, costs sored to 100 million EG. On the other hand, plot sizes were huge because it was thought that this would promote their saleability and to cover the cost of building new houses for displaced residents. In the event, the plots were unaffordable because the site was still surrounded by poor buildings, warehouses and unplanned streets. A few planners, who were against demolishing the ishash, explained that the entire gesture would be inconvenient and infeasible. They claimed that the process was one of in-filling the site with high-rise projects that were competing with a surrounding context and that failure could have been predicted. Some added that it was a naive solution to represent Cairo in a modern image and apply order to what was thought to be a different reality in Bulaq - the reality of the poor versus that of the wealthy. This corresponds more closely to Timothy Mitchell's (1988) world as an exhibition (Figure 3).

The outcome of futile initiatives of this nature was that new housing targets were not met, leaving streetscapes with many empty lots and absentee residents. A kind of 
political resistance that forms a different landscape to that for which it was planned, remained for at least 25 years after the evacuation. It was a milestone of failure to set unrealistic plans for change, especially when businessmen and investors later noted that the site was unsuitable for investment. The residents explained how people no longer communicated their previous healthy social networks and everyday encounters. Despite al Tourguman's vibrant and ideal location for CDD investment, it developed into an outcast ghetto and even fostered greater isolation from the city's urban life than ever before (MARCUSE, 1997). The reliability and transparency of the state have always been problematic, especially in terms of communicating political messages through local schemes like this. Equally, it may be that forcible eviction was a tool used by the state to expel the residents with no underlying plans to rehouse them (interview). 


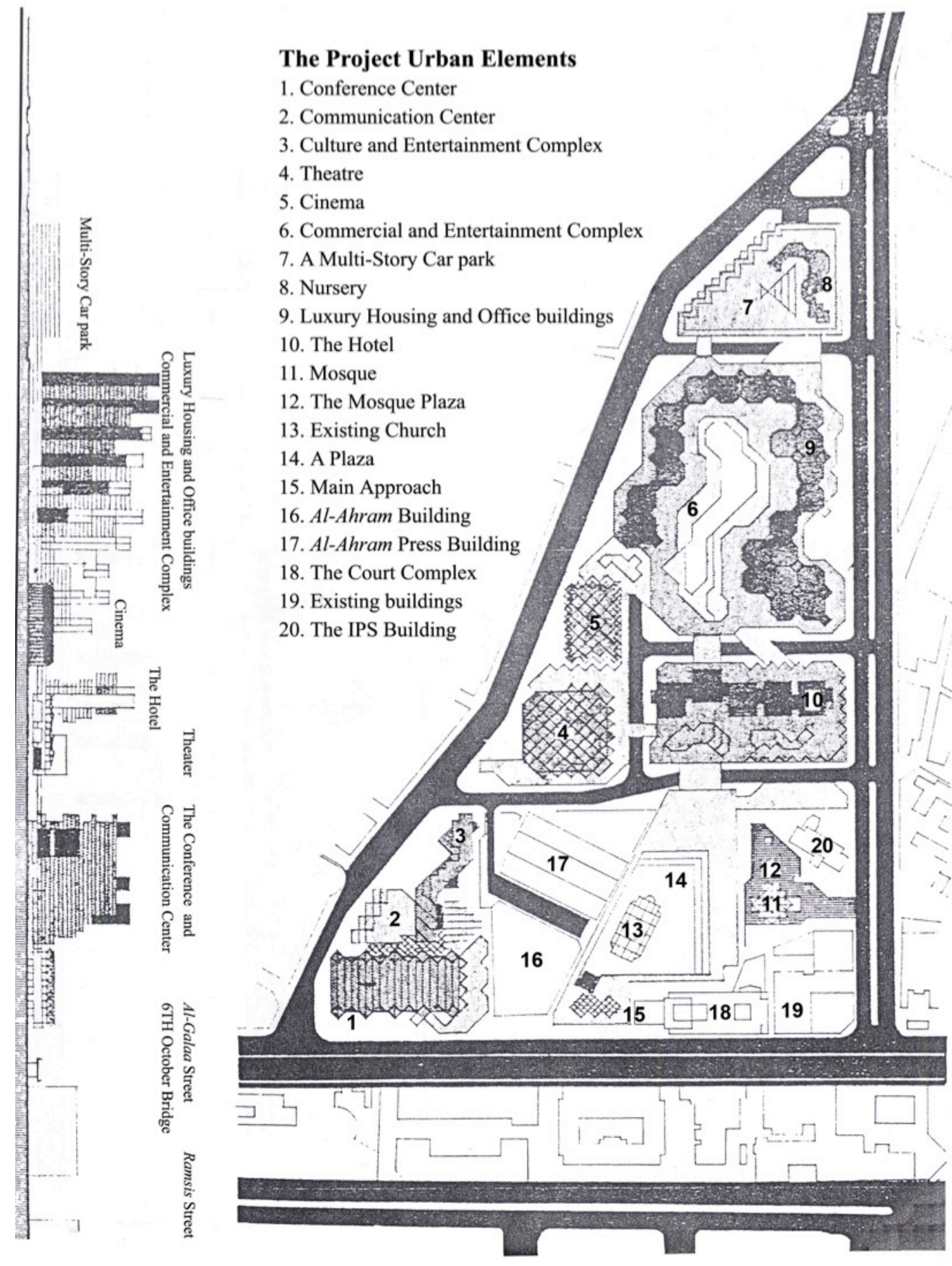

Fig. 3 The upgrading Planning scheme.

Source: Ishash al-Tourguman re-planning scheme Report 1979, GOPP, Cairo. 


\section{REMEBERING THE SCARS: OLD MEMORIES, NEW SPACES}

Literature on collective memory shows how constantly incidents of the past are tied in fundamentally with social networks and landscapes (BOYER, 1994; HALBWACHS, 1980; HEYNEN, 1999; ABDELMONEM \& SELIM, 2012). Memory occurs in the present to inform our habitual associations and way of life, not distinct from its archaeological presence. It is not surprising to observe controversial perceptions among social groups when they recall stories of the past and their living spaces. They usually tend to link their stories with places and physical objects to establish a thread of memory that may or may not be sites that witnessed suffering or disturbance. Yet, the place and its object dimensions and attributes become the most durable part of this fabric, through objects of remembrance (BEVAN, 2006). Buildings and urban spaces are symbolic evidence of certain social networks and practices. There are indeed some memorised projects, like urban renewal or changing landscapes, which attempt to obstruct public dialogue and are appreciated as signs of forgetting the past, with an entire community disappearing and leaving behind its physical manifestations: buildings and spaces. Yet, spaces cannot mysteriously embody memories by the quality of their existence, just as the city cannot disclose history without supporting narratives (ibid.). In fact, societies retain their memory through continuous and sustainable performance of acts, rituals and normative social behaviour.

On the other hand, places have meanings that exceed their forms as authored illustrations of the past and methods by which social groups experience them. In fact, the wounds of al Tourguman emerged through conflicting pasts as zones of transition and social change to materialise transformation. Wounds also thrived through its residents, not only the groups that suffered the consequences of eviction but also those that had witnessed the razed for prospect development encountering and opposing state violence and the trauma of displacement. Under the increasing spread of differences in postmodern societies, class and social segregation follow distinct pathways and occupy different zones of the city, so that the wealthy hardly encounter the 'unwanted' others (MITCHELL, 2003). Indeed, this idea will never arise without visions of a strong country protecting its citizens from the 'unwanted' beyond its boundaries, 'changing in this sense our rooted sympathies of what constitutes the public to legitimate new forms of urban structures through environmental change, behaviour modification and stringent policing' (ibid., p. 4).

Fullilove (2004) argues that a 'root shock' threatens the ability of any person to function just as much as when they lose vast amounts of blood, simply because we all have strong social and emotional links with the places we inhabit. Thus, for us, place always develops as a protective shelter for our social and ecosystem associations. These qualities are not about local forms of owning or claiming the place but rather about the connections and structures of sentimental networks that give thick meaning to a citizen's experience, one that associates more widely with place than human subjects themselves (BENNETT, 2005, p. 10). This understanding opens for us different channels to express and communicate sensory emotions about places, rendering their distinct histories.

After the relocation incident, the ishash became an anchor for its former residents' sense of belonging and took precedence over other associations. But the remaining 
groups became vital raconteurs of the incident and its aftermath. Many still form the elderly population living in Bulaq who either memorise or witnessed the confrontation with the armed police. They explained how state actions disrupted their inveterate relations to the geographies of the place and that the inconsistencies produced in this process created odd grounds for people and places that, for many years, did not understand why their neighbours had been banished. Despite living in slums, their rooted habits, practices and cultures signified a sustainable process of collective settlement, communicating a robust social message that they were connected groups that felt highly safe and secure (SELIM, 2015).

People's reminiscences on the hardships of living in the ishash are closely related to the housing conditions described as 'ruins'. However, they always cite their easy access to other parts of Cairo, marketplaces and cheap goods. One informant explained that 'When our past neighbours baked something, the good smell would reach us from a distance and we would share the food. People tend to eat together and support each other during difficult times' (interview). Local vendors also utilised al Tourguman lands to sell cooked foods, sugarcane and fresh vegetables. Others occupied the space to disseminate some of their home-based goods or set up bakery ovens for simple pastries. The area was a hub for young teenagers to gather and interact with others. While these activities gradually encouraged the presence of people, the area became empty, dark and potentially unsafe for women and young children, especially at night when its original occupants vanished in no time. However, the continuous presence of people ensured assistance when needed. People were always ready to help prevent a fight or protect a child. Being seen by others provided social control that allowed more freedom of movement for women and legitimised their interaction with men.

Activities of unknown neighbours and the mixing of people from different parts of Cairo influenced the view of the empty lands and surrounding spaces. The new spatial settings supported restructuring the interaction between the residents and, in particular, others, and the way they observed public space. This shift was epitomised by growing restrictions on access and use of spaces following the evacuation, which was mostly driven by fear. Feelings of belonging to al Tourguman were symbolised in a way that connects its residents with the past and appears to show a collective reference that articulates its support for state policing actions. Indeed, insecurity and an unknown future made for stress among the remaining population. They were mostly conscious that they would be subject to similar traumatic situations at any time and, somehow, were prepared for it. They were also aware that armed evacuation was also going ahead in other neighbourhoods in the city, like in the Ayn Hilwan dwellings of old Cairo and the al-Marg area. These and other unexpected incidents were aired in the media, showing armed police surrounding these houses to evacuate families by force.

\section{CONCLUSION}

Al-Tourguman and other similar sites in Cairo represented places where the status of local people has remained a significant social and political issue, and, over time, has become central to local conflict. The conflict also emerged as a struggle over landscapes for personal, group and national identity, and meaning and belonging. In fact, relocation is not only about moving people from one place to another but about 
how it affects life and socio-spatial relationships within the local community. Sites defined by scars and wounds not only exist as imaginary and/or physical locales but endure as 'behaviours and occasions for memory and intervention' (ROACH, 1996, p. xi). While everyday exemplified knowledge of inhabited places is taken for granted, eviction enables it spectators to possess firmer bonds with their former living place based on attachments that disengaged them from their childhood connections. In all ways, some residents remained in the ishash gave rise to another level of loss. They collectively formed a sound, chronic and inveterate narrative that was slowly constructed after the immediate relocation losses. Indeed, the indigenous stabilisation of communities is fragmented once places are demolished.

The ishash residents, through their stories, raised moral inquiries about the politics of place making driven by urban upgrading. They called attention to their association with place, its mental memory and inspiration in making a just and unique life. They also challenged the invisible status the city authorities bestowed on them and have no capacity for state building. Yet, their commendable survival over almost four decades since the traumatic incident documents their existence through everyday encounters and use of space, thereby claiming individual and collective rights to their city. They also enact their habitual engagements with vibrant places like Bulaq evidencing their cognitive and emotional attachments, spatial and social memories, and fragile social systems. Still, their interpretations always reveal a bounded selftension between the recognition of state violence and anxieties about the unknown future they face when hoping to survive.

In fact, new forms of public memory could be structured and transferred to the inhabitants through their intergenerational social outreach that offers social stability and security, despite the ongoing ruptures of geographical segregation and exclusion. However, it is suggested that place memory is usually a complicated case to resolve. Communities usually tend to define themselves through their physical and social environments but will not always accept a place's depressing history. Indeed, when individuals return to places that have witnessed violence and pain, they find themselves trapped in horrific images of the past, with living memories and emotional attachments. Similarly, displaced groups tend to revisit their friends and relatives back in the ishash, and some will even shop and buy goods from traders they used to know. That is why social change must be counted as both loss and opportunity, particularly when chunks of the city become detached from other spaces.

\section{REFERENCES}

ABDELMONEM, MG. and SELIM, G. 2012, Architecture, memory and historical continuity in old Cairo. Journal of Architecture. Vol. 17/2, pp.167-192.

BENNETT, J. 2005, Empathic Vision: Affect, Trauma, and Contemporary Art. Stanford University Press, Stanford.

BEVAN, R. 2006, The Destruction of Memory. Reaktion, London.

BLUNT, A. and MCEWAN, C. 2002, Postcolonial Geographies. Continuum, London. 
Architectural Entertainments. The MIT Press, Cambridge, Mass.

CASTELLS, M. 1972, Urban renewal and social conflict in Paris. Social Science Information. Vol.11, pp. 93-124.

DAVIES, J. 2014, Rethinking urban power and the local state: Hegemony, domination and resistance in neoliberal cities. Urban Studies. Vol. 51/15, pp. 32153232.

ELLIN, N. 1999, Postmodern Urbanism. Princeton Architectural Press, Princeton.

FULLILOVE, MT. 2004, Root shock: How Tearing up City Neighborhoods Hurts America, and what We Can Do about It. One World/Ballatine Press, New York.

GHANNAM, F. 2002, Remaking the Modern: Space, Relocation, and the Politics of Identity in a Global Cairo. University of California Press, Berkeley and London.

HALBWACHS, M. 1980, The Collective Memory (Ditter, FJ. \& Ditter, VY. trans.) Harper \& Row, New York.

HARVEY, D. 2003, The city as a body politic, In: Schneider, J. \& Susser, I. (ed.) Wounded Cities, Berg, Oxford and New York, pp. 25-44.

HEYNEN, H. 1999, Petrifying memories: architecture and the construction of identity. The Journal of Architecture. Vol. 4, 369-391.

KEARNEY, A. 2012, Ethnicity in wounded spaces: instrumentalism and the making of Africa in Brazil, nineteen sixty nine (NSN). Ethnic studies journal. Vol. 1(1), pp. 39-55.

LEFEBVRE, H. 1991, The Production of Space (Nicholson-Smith D, trans.). Basil Blackwell, Oxford.

MARCUSE, P. 1997, The enclave, the citadel, and the ghetto: what has changed in the post-Fordist U.S. city. Urban Affairs Review. Vol. 33, pp. 228-264.

MITCHELL, D. 2003, The Right to the City: Social Justice and the Right for Public Space. Guilford Press, New York.

MITCHELL, T. 1988, Colonizing Egypt. University of California Press, Berkeley and Oxford.

ROACH, J. 1996, Cities of the Dead: Circum-Atlantic Performance. Columbia University Press, New York.

ROSE, DB. 1996, Rupture and the Ethics of Care in Colonized Space. In: Prehistory to Politics: John Mulvaney, the Humanities and the Public Intellectual (eds.) Tim Bonyhady \& Tom Griffiths. Melbourne University Press, Melbourne. 
RUGH, A. 1979, Coping with Poverty in a Cairo Community. The American University in Cairo Press, Cairo.

SELIM, G. 2015, (Re) making trajectories: Eviction, control and power, Habitat International. Vol. 48, pp. 219-226.

SIMONE, AM. 2010. City Life from Jakarta to Dakar. Routledge, New York and London.

ZUKIN, S. 1995, The Cultures of Cities. Blackwell. Oxford. 